\title{
Study on Income Tax Enforcement of Family Trusts: Based on the Principle of Substantial Taxation
}

\author{
Jiangyu Huang ${ }^{1}$, Qiuyan Xie ${ }^{1}$, Jing $\mathrm{Li}^{2}{ }^{2}$ * \\ ${ }^{1}$ College of Big Data Application and Economics, Guizhou University of Finance and Economics, Guiyang, China \\ ${ }^{2}$ Faculty of Management and Economics, Kunming University of Science and Technology, Kunming, China
}

\author{
Email address: \\ woshiqudeyiqie@163.com (Jing Li) \\ ${ }^{*}$ Corresponding author
}

\section{To cite this article:}

Jiangyu Huang, Qiuyan Xie, Jing Li. Study on Income Tax Enforcement of Family Trusts: Based on the Principle of Substantial Taxation. American Journal of Theoretical and Applied Business. Vol. 6, No. 4, 2020, pp. 106-111. doi: 10.11648/j.ajtab.20200604.18

Received: December 18, 2020; Accepted: December 28, 2020; Published: December 31, 2020

\begin{abstract}
Family trust is an important innovation in the development of financial technology and digital economy. As an innovative method for family business wealth preservation, appreciation and inheritance, family trusts play an important role in financial markets and social safety nets. The healthy operation of family trusts is inseparable from a good tax collection and management system. This study is based on case analysis and international comparative law, combined with the particularity of family trusts, and analyzes the risks that may be faced in its income tax enforcement. The research found that the insufficient regulations of family trust policies make tax collection and administration face the risks of double taxation, tax loss, and high tax administration cost. Based on the substantive tax principles and the perspective of the sustainable development of family trusts, the research puts forward suggestions on the improvement of income tax collection and management in Chinese family trusts: The design of family trusts and taxation systems should insist on substantive taxation; combine the theory of trust conduit with the theory of trust entities; clarify the time, scope, beneficiary, and choice of accounting standards for family trust collection. In the era of digital economy, governments, enterprises, and educational institutions have formed partnerships to strengthen the education of family trust investors on financial, taxation, and digital economy requirements. Taking the sustainable development of family trusts as the starting point, build a new momentum and social safety net for China's economic and social development.
\end{abstract}

Keywords: Family Trust, Income Tax, Principle of Substantial Taxation, Digital Economy

\section{Introduction}

According to the statistics of the "Hurun Wealth Report 2019", the number of high-net-worth households in China is on a rapid rise, and the number of households with assets exceeding 10 million accounts for nearly $50 \%$. The inheritance, appreciation and preservation of the wealth of these high-net-worth families have become important social issues. Family trust is a way to inherit wealth, increase value, and maintain value. Murdoch, the manager of a world-renowned media company, established a family trust, and two-fifths of its assets are managed by the family trust fund. Family trust is used as an important financial management and inheritance distribution tool by family enterprises in developed countries, and has unique advantages.
As an important way to preserve and increase the value of family wealth, it is difficult to levy income tax on family trusts. This article mainly studies the obstacles faced by the actual tax enforcement of family trusts. China's family trust and taxation system are insufficiently connected, lack of guidance on taxation subjects and taxation standards, and fail to effectively reflect the principle of tax fairness in the time and scope of taxation.

This paper compares and analyzes the typical practices of income tax in family trusts, which has theoretical and practical significance for the construction of Chinese family trust system and the prevention of tax loss.

The global family trust industry is developing rapidly, and the tax enforcement of family trusts in various countries is unique. Family trusts can be traced back to ancient Rome. Ancient Romans managed and operated their own property 
through trusted third-party institutions. The family trust system is conducive to the inheritance of family wealth $[1,2]$. In the practice of income tax enforcement of Chinese family trusts, the operational risk of double taxation is prone to appear. The trust products launched by Ping An Company in 2013 have a greater impact in China. Some scholars have summarized the advantages of the family trust system, and compared with other wealth inheritance systems, the study found that family trust has better confidentiality, tax planning and bankruptcy isolation [3]. The policy design of income tax enforcement of Chinese family trusts can learn from the practical experience of the civil law system and the common law system. Academic research recommendations: Tax enforcement should clarify the subject of taxation, adhere to the principles of substantive taxation, family property taxation and family trust management theory, and improve the tax system related to family trusts based on the particularity of the stage [4]. China's tax system should follow the principles of legal taxation, tax efficiency, tax fairness and substantial taxation, and compare the characteristics of the main tax types in the trust process [5]. In view of the income tax collection and management risks in family trusts, some scholars suggested that the tax time should be clarified, the special clauses of family trusts should be added, and the dual ownership system should be established, so as to promote the development of family trust industry through the taxation business environment [6].

Existing research provides important experience for family trust and income tax collection and management research: First, family trusts have the characteristics of property confidentiality, tax planning and bankruptcy isolation; Second, the construction of the tax system should follow a variety of principles, including the legal principle of taxation, the principle of tax fairness and efficiency, and the principle of substantive taxation; Third, China should clarify the taxpayers in family trusts and adhere to the theory of substantive taxation and family trust management.

Existing studies have found that: First, the operation of the tax refund mechanism is too complicated for the issue of double taxation; second, the taxation subject and taxation standards of Chinese family trusts can be further clarified. This article analyzes the income tax issues of family trusts based on case analysis and comparison methods. Scholars attach importance to the improvement of the taxation system to promote the development of the family trust industry. The research pays little attention to the integration and practice of Chinese family trust and income tax system, and seldom analyzes the tax enforcement issues in family trusts from the perspective of international comparison.

\section{The Basic Theory of Tax Enforcement in Family Trusts}

\subsection{Current Status of Chinese Family Trusts}

The development of family trusts in China has a long history, and family trusts are showing a growing trend. According to big data statistics, Chinese family private enterprises account for nearly $90 \%$ of China's private enterprises. With the acceleration of generational turnover, more high-net-worth families will face pressure to inherit property. Important events in the development of China's trust industry are shown in Table 1.

Table 1. Major events in the development of China's trust industry.

\begin{tabular}{ll}
\hline Time of policies & Main Contents \\
\hline 2001.10 & $\begin{array}{l}\text { China implements the "Trust Law." A trust is an act of management or disposal carried out by the trustee in accordance with the wishes of } \\
\text { the trustor for the benefit of the beneficiary. }\end{array}$ \\
2003.03 & $\begin{array}{l}\text { Notice on Strengthening the Financial Management of Enterprises' External Donations, The policy stipulates the adjustment of the scope } \\
\text { of external donations by trust companies. }\end{array}$ \\
2007.03 & China has implemented the "Administrative Measures for Trust Companies" to regulate the conduct of trust companies. \\
2012.09 & Ping An Trust released the first family trust in China. \\
2014.05 & Chinese companies have jointly launched a series of innovative products for the domestic high-end consumer market: insurance trusts. \\
2015.02 & CITIC Trust landed the first single family trust to promote the further development of China's trust industry. \\
2016.01 & China promulgated the "Notice on Corporate Income Tax Policy Issues for Public Interest Donations." \\
2018.08 & China issued the "Arrangements of the Ministry of Trust on Strengthening the Trust Supervision Work during the Transitional Period of \\
& $\begin{array}{l}\text { Management of Assets Management". } \\
\text { China issued the Interim Measures for the Management of Equity in Trust Companies. The equity management of trust companies shall follow } \\
\text { the principles of classified management, excellent stability, clear structure, clear rights and responsibilities, orderly changes, transparency and }\end{array}$ \\
integrity. & China promotes the implementation of the "Interim Measures for the Management of Funds and Trusts of Trust Companies." \\
2019.10 &
\end{tabular}

\subsection{Theoretical Analysis of Family Trust}

The income tax system of family trusts in civil law countries is generally based on the theory of trust conduits. For example, Japan, based on the trust conduit theory, divides trusts into self-interest trusts and other-interest trusts [7].

Among the countries in the common law system, the United Kingdom adopts the trust entity theory. The theory of trust entities believes that a trust can be used as an independent taxation entity to substantively levy taxes on income. The tax time is when the trust's income changes [8]. If the trust entity theory is adopted, the enforcement of income tax on family trusts has the function of accumulating or delaying payment. The beneficiaries tend to use this time period to adjust the tax year, resulting in tax evasion. The system design of the income tax of the family trust should prevent tax loss. 


\subsection{The basic Connotation of Taxation of Family Trust}

In 1982, the concept of "family trust" first appeared in the American trust industry. A family trust is based on the family, which involves the three-party relationship between the trustor, the beneficiary and the trustee. The trustee, in accordance with the trustor's wishes, realizes the goal of maintaining the value of the family's property, adding value, and supporting and avoiding risks for the beneficiaries. Family trusts can designate beneficiaries. The trust does not substantially change the ownership of the trust property.

Few countries have formal legal interpretations of family trusts. Trusts related to the preservation and appreciation of family property can be understood as family trusts. A trust means that the trustor transfers family wealth to the trustee, and the trustee manages the family wealth according to the trustor's wishes, so that the family wealth can be protected, inherited, and valued. In the era of digital economy, trust management is more transparent [9]. Data-based trust enables more effective supervision of family trusts. The risk of income tax enforcement in family trusts is supervised by the government.

\section{Analysis on the Issues of Income Tax Enforcement in Family Trust}

The legal policies of Chinese family trusts can be further improved, and the taxpayers of family trusts need to be clarified. Family trusts are mainly based on the "Trust Law". In the tax enforcement of family trusts, there is a lack of matching fiscal and taxation systems, a lack of uniform benchmarks in terms of taxpayers, taxation methods and applicable tax rates, and there is a risk of double taxation and tax loss in tax collection. Some high-net-worth families make excessive use of tax planning for tax avoidance, which may cause tax losses.

\subsection{It Is Difficult to Determine the Tax Subject and Tax Standard of a Family Trust}

Taxation in family trusts mainly follows general taxation principles. The development of family trusts requires matching tax policies. The complex system design of family trusts will conceal the true taxpayers of income tax. Income tax policies of family trust are quite vague, and tax law enforcement officers have deviations in the application of tax policies.

The beneficiary is the taxpayer of the income tax of the family trust, and the tax object of the income tax of the family trust is the benefits enjoyed by the beneficiary and the benefits that may be enjoyed in the future. The benefits that may be enjoyed by the beneficiaries of a family trust have not been distributed, which is difficult to estimate and uncertain. It is difficult to determine the tax object, scope and time of the property of a family trust. Punishment measures for taxpayers in family trusts that fail to report to tax authorities in time. Existing policies lack a fiscal and taxation system that matches family trusts. It is more difficult for tax authorities to calculate the undistributed or temporarily uncertain family trust income, and it is more difficult for the beneficiaries to pre-collect family trust income tax. The link between policy and practice will affect the efficiency of tax administration of taxation departments.

\subsection{The taxation Scope of Family Income Tax Needs to Be Clarified}

The taxation scope of family trust is the income generated in the process of management, preservation and appreciation of family property. It is reasonable to include the income of trust property into the scope of income tax enforcement. When a family trust is established, it will transfer the future income rights of the family trust to the beneficiary. Whether the beneficiary's income should be taxed or not is to be clearly classified according to the type of beneficiary's behavior. If there is an operating activity, the legal trust property will be treated as accidental income, and personal income tax will be levied on the beneficiaries in accordance with the "Individual Income Tax Law"; if it is a gift, it is difficult to levy income tax on this part of the family trust property, which will easily lead to tax loss.

\subsection{Double Taxation and Unfair Taxation in Family Trusts}

China implements the ownership system of "one property, one right", and does not implement a dual ownership property system for tax enforcement of family trust properties. Due to the characteristics of the trust tax system, there is a risk of double taxation and unfair tax burden.

According to the current trust system, the income tax collection of family trusts is mainly in the generation and distribution stages. When the family trust property generates income, the taxpayer needs to pay tax; when the trustee distributes the family trust income, the taxpayer needs to pay taxes again, which leads to double taxation. For example, when the collection standards for equity and real estate family trusts are not uniform, law enforcement agencies levy taxes in the form of property transfers, which is likely to cause double taxation [10].

For example, capital trusts include securities investment funds, and securities investment funds include open-end securities investment funds. Income tax is temporarily not levied on the income obtained by institutional investors or individuals in fund distribution. Other forms of fund trusts need to pay higher tax burdens, which will cause unfair tax burdens.

\subsection{It Is Difficult for Tax Administration Departments to Administer the Tax Enforcement of Family Trusts}

The ambiguity of policy regulations makes it more difficult for law enforcement officers to collect and manage family trust income tax.

Tax enforcement officers apply different applications to the tax collection and administration of family trusts. Inconsistent collection and management standards and insufficient 
information disclosure increase the risk of tax loss for family trusts. The taxation system for the transfer of family trust property is lacking, and it is necessary to distinguish between monetary and non-monetary properties in family trust property[11]. The cost of converting monetary assets into family trust assets is relatively low, and the trustee, entrusting party and beneficiary are not required to pay taxes; the cost of converting non-monetary assets into family trust property is relatively high. The owner of real property changes to a trustee. According to the nature of the transaction, transactions deemed to be sales require higher income taxes.

\section{Different Methods of Collecting Income Tax in Family Trusts}

\subsection{Tax Refund Mechanism on the Issue of Double Taxation}

The United Kingdom (UK) adopts a tax refund mechanism on the issue of double taxation, which is calculated according to the basic tax rate of personal income tax.

For the cumulative benefits generated by the family trust, the beneficiary needs to pay part of the additional tax to meet the principle of tax fairness. This approach is conducive to improving taxpayers' tax compliance.

In terms of taxpayers' cumulative benefits, child allowances, and tax incentives, anti-avoidance laws have been established to prevent taxpayers from over-using tax planning. These measures can well reduce the occurrence of double taxation. The process of the tax refund mechanism of British family trusts is too complicated, which increases the difficulty of tax administration and reduces the administrative efficiency of the tax agency.

\subsection{Reduction and Exemption Distribution Method to Double Taxation of Family Trusts}

The trust industry in the United States is developing rapidly. American family businesses focus on property management and the inheritance of personal and family property. Family trusts in the United States adopt a compound mechanism that combines conduit entities and taxable entities. Under this mechanism, the tax objects are the trust itself and the beneficiaries. When calculating the income tax, the taxpayer's taxable income is determined directly through the reduction and exemption of distribution in the family trust. The tax that should be paid by the beneficiaries and the trust itself is distributed in proportion, and the trustee of the family trust does not need to pay all the taxes [13]. The family trust adopts a reduction and exemption distribution method, so that the beneficiary only bears part of the tax. While improving the efficiency of tax enforcement, it also reduces the tax burden of beneficiaries.

\subsection{Legal System to Regulate Double Taxation}

As a typical civil law country, Japan follows the principle of "one property, one right". Japan has formulated a legal system that is compatible with family trusts. Japan adheres to the theory of trust conduits. On the issue of double taxation, it clearly distinguishes the generation stage and the distribution stage of the income of family trusts, and it is clear that the essence of taxation obligations is the substantial transfer of family property. Specific provisions are made for the two stages of income generation and distribution of family trusts, distinguishing whether the property is transferred in form or the tax liability caused by substantive transfer.

In the establishment stage, if the settlor of the family trust is an individual, there is no need to levy the income tax of the family trust; if the settlor of the family trust is an enterprise, it needs to be taxed according to the family trust income. In the subsistence stage, the trustee manages the property according to the client's wishes, and the trustee does not obtain the income and ownership of the family property. In the termination phase, the trustee, the entrusting party and the beneficiary do not need to pay taxes.

The similarities in the tax enforcement of family trusts in the above countries include:adhere to substantive taxation, adhere to the principles of legal taxation, tax efficiency and tax fairness; the income tax of family trusts is generally paid by the beneficiary [12]. Regarding the issue of double taxation, the United Kingdom adopts a tax rebate mechanism, while the United States adopts a compound mechanism combining taxable entities and conduit entities. Japan divides the income phase of family trusts into two phases: the time of occurrence and the time of distribution.

\section{Suggestions on Improving Income Tax Enforcement in Chinese Family Trusts}

International experience has brought useful inspiration to the development of Chinese family trusts. First, for the problem of double taxation, the UK's tax refund principle can be adopted, based on the basic tax rate of personal income tax or the development status of family trusts, the progressive tax rate is set, and the cumulative benefit generated by family property is taxed. Second, the government has formulated anti-tax avoidance laws to prevent offshore families from using "tax havens" to avoid excessive taxes, causing tax losses[14]. Third, in terms of system design, the government can use a combination of trust conduit and trust entity theory. Fourth, the government should formulate a legal system compatible with family trusts, follow the principle of substantive taxation, and find the development direction of family trusts.

\subsection{Special Provisions for Family Trust Income Tax Are Added to the Trust Policy}

On the basis of adhering to the principle of "one property, one right" in the civil law, China can appropriately revise and improve the income tax collection and management of family trusts. In the existing trust law system, the effective connection between family trusts and income tax will facilitate tax enforcement by tax authorities. Family trusts are mainly limited to family members to facilitate the inheritance, protection and management of family wealth. From the 
perspective of substantive taxation, there is no need to pay taxes when there is no substantial change in ownership. Regarding the substantial change in the act of gift, the taxation scope of the income tax should be clarified.

\subsection{Reasonably Adjust the Income Tax Time of Family Trusts}

Accounting confirmation tax time includes income realization system and accrual system. The income realization system is to confirm the taxable income when the payment is received. This method cannot tax the undistributed and temporarily uncertain income of the beneficiaries. Under the accrual system, regardless of whether the family trust income actually occurs, the taxable income of the family trust should be confirmed during the existence of the family trust. This method will cause the beneficiaries to pay taxes in advance even though they have not actually received the money. The tax payable of a family trust should be based on the benefit situation to choose the realization system or the accrual system.

The government follows the principle of substantive taxation and pursues the dual goals of fair taxation and prevention of tax losses.

When the beneficiary is an enterprise, the accrual system can be selected. If the beneficiary is unable to pay taxes, the trustee can be regarded as the withholding agent first, and the trustee should first advance the family trust income tax; If the beneficiary is a natural person, the payment realization system can be adopted. This is conducive to reducing the cost of tax enforcement in family trusts.

\subsection{Tax Conduit Principle Promotes tax Enforcement of Family Trusts}

The principle of substantive taxation is to determine the taxpayer's tax burden based on the taxpayer's true affordability.

Trust conduit and substantive taxation principles complement each other. The principle of substantive taxation can better solve the problem of double taxation of family trusts better clarify taxpayers and improve the efficiency of tax authorities; The principle of family trust can clarify taxpayers' taxation obligations and reduce the risk of tax loss.

\section{Conclusion}

This article mainly adopts case analysis method and international comparative law to study the risk of income tax collection and management in family trust. The research suggests that the government should insist on substantive taxation, improve the time and scope of income tax payment, and add family trusts and special income tax provisions.

Family trusts have become an important choice for family business wealth preservation and appreciation. The innovation of family trusts in asset management will put forward higher requirements for tax collection and management. The development of Chinese family trusts will further focus on art family trusts and overseas family trusts.
Quantitative and qualitative methods should be fully utilized in the future research on the combination of family trust and tax collection and management. On the basis of international comparison, based on domestic development practice and needs, conduct in-depth empirical and theoretical research. The development of family trusts must be combined with the development of the digital economy. Governments, enterprises, and individuals must pay attention to the new opportunities and challenges that big data technology brings to tax collection and management, and promote the sustainable development of family trusts.

The combination of family trust and digital economy reflects the new trend of financial technology. Based on supply and demand, the tax system must actively adapt to changes in the industrial structure of family trusts. The government must participate in the technological upgrade of big data, deeply participate in the product design and innovation of family trusts, and continue to promote the healthy development of the economy and society based on family businesses and trust.

Family trust is an important financial innovation, and good tax collection is the guarantee of its healthy development. The government should attach importance to the financial and digital education of trust investors and cultivate qualified investors. Investors in family trusts use the digital economy platform to promote the digital transformation of enterprises.

Governments, enterprises, and educational institutions form partnerships to build systematic financial education, and modern information technology makes the combined development of trust and digital technology more vital. Sustainable economic and social development will better realize effective taxation governance.

The sustainable development of family trusts will bring stable and sustainable tax sources. The sound development of the family trust industry will promote the prosperity of the industry and play an important role in promoting sustainable poverty reduction and rural revitalization strategies. Trust reflects a country's credit system and financial market environment [16]. A good tax system plays an important role in the effective combination of finance and the real economy. Family businesses involve thousands of households and the economic and social stability of a country. They are an important guarantee for the social safety net.

\section{Acknowledgements}

This research is financially supported by "Research on Cultivation of Big Data Thinking and Application Ability of University Undergraduates: Based on the Perspective of Digital Economy" (GZJG20200203).

\section{References}

[1] Schwarz, D. E, Sommer E (2020). Feasible smooth income tax schedules: benefits and distributional implications. Applied Economics, 52. 
[2] Agranov M, Palfrey T R (2020). The effects of income mobility and tax persistence on income redistribution and inequality [J]. European Economic Review, 123.

[3] Huang, J. Y. (2016). Research on the Tax Collection and Management of Chinese Family Trust. Journal of Mianyang Teachers' College, 2016, 35 (01):30-34.

[4] Shi, X. P, Zhao, J (2019). The Difficulties and Countermeasures of Taxation of Family Trust Income. Taxation Research, 2019 (11):119-123.

[5] Jiang, W. J. (2018). The construction of China's trust tax system: Based on the current tax system and international reference. China Management Informationization, (21):125-128

[6] Qu, L. L (2018). Redefinition of overseas family trusts: under the new tax law. Modern Commercial Banking, (22):81-83.

[7] Charlet. D, Lecha, V. P. (2005). Voice Biometrics Within the Family: Trust, Privacy and Personalisation. International Conference on E-Business and Telecommunication Networks. Springer, Berlin, Heidelberg.

[8] Hauswald, H. (2013). Antecedents and outcomes of stakeholder trust in family businesses-An application of the integrative model of organizational trust. In: Stakeholder Trust in Family Businesses. Familienunternehmen und KMU. Springer Gabler, Wiesbaden.
[9] Goodwin, I. (2013). How the Rich Stay Rich: Using a Family Trust Company to Secure a Family Fortune, College of Law Faculty Scholarship.

[10] Chamu, Sundaramurthy (2008). Sustaining Trust Within Family Businesses. Family Business Review, 21 (1): 89-102.

[11] Hadjielias, E, Poutziouris, P. (2015). On the conditions for the cooperative relations between family businesses: the role of trust. International Journal of Entrepreneurial Behaviour \& Research, 21 (6): 867-897.

[12] Bawa, S. G, Vu, N. T. (2020). International effects of corporate tax cuts on income distribution. Review of International Economics, (2).

[13] Bethencourt, C, Kunze, L. (2020). Social norms and economic growth in a model with labor and capital income tax evasion. Economic Modelling, 86.

[14] Mirrlees J A (1971). The Theory of Optimal Income Taxation. Review of Economic Studies, 38 (114): 175-208.

[15] Bornman M, Wassermann M (2020). Tax knowledge for the digital economy. Journal of Economic and Financial Sciences, $13(1)$.

[16] Tsindeliani I, Kot S, Vasilyeva E, et al (2019). Tax System of the Russian Federation: Current State and Steps towards Financial Sustainability. Sustainability, 11. 